\title{
Development and Suggestion of a Cardiac CTA Scoring System for the Prediction of Revascularization Success in Chronic Total Occlusions (CTO) of the Coronary Arteries
}

\section{Entwicklung eines auf der CTA basierendem Punktesystem zur Evaluierung des Revaskularisationserfolges von chronisch totalen Okklusionen der Koronararterien}

Authors

Affiliations

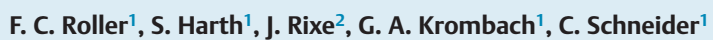

Department of Radiology, Justus Liebig University Giessen, Giessen, Germany

Department of Cardiology, Justus Liebig University Giessen, Giessen, Germany

\author{
Key words \\ - cardiac \\ - heart \\ - angiography \\ - interventional procedures \\ - CT angiography
}

received 16.6.2015

accepted 28.9.2015

Bibliography

DOI http://dx.doi.org/

10.1055/s-0041-108199

Published online: 3.12.2015

Fortschr Röntgenstr 2016; 188 :

172-178 @ Georg Thieme

Verlag KG Stuttgart - New York . ISSN 1438-9029

\section{Correspondence}

Herr Dr. Fritz Christian Roller

Radiologie, Universitätsklinikum Giessen

Klinikstraße 36

35392 Giessen

Germany

Tel.: ++ 49/06 41/98556329

Fax: ++49/06 41/98541809

fritz.c.roller@radiol.med.uni-

giessen.de

\section{Zusammenfassung}

$\nabla$

Ziel: Es konnte gezeigt werden, dass sich eine präinterventionelle Analyse von chronisch totalen Okklusionen (CTO) der Koronararterien mittels kardialer CTA positiv auf den Revaskularisationserfolg auswirkt. Das Ziel unserer Studie war es ein CTAgestütztes Punktesystem zur Vorhersage des Revaskularisationserfolges bei CTO zu entwickeln.

Material und Methoden: Bei 41 konsekutive Patienten (30 männlich; 63,1 Jahre +/- 8,3 Standardabweichung) mit CTO der Koronararterien wurde eine kardiale CTA vor dem Revaskularisationsversuch durchgeführt. Alle СTO wurden in der kardialen CTA bezüglich besonderer Merkmale und ohne Kenntnis des Revaskularisationserfolges durch 2 Radiologen in Konsensus beurteilt. Alle Merkmale wurden hinsichtlich ihrer Verteilung zwischen den Erfolgsgruppen analysiert. Für das Vorhandensein eines besonderen Merkmales mit ungleicher Verteilung zwischen den Erfolgsgruppen wurde jeweils ein Punkt vergeben und eine Gesamtpunktzahl für jede CTO berechnet.

Ergebnisse: Schwere (Misserfolgsgruppe 68,8\% vs. Erfolgsgruppe $28,0 \% ; \mathrm{p}<0,02)$ und intraluminale Kalzifikationen (68,8\%; 40,0\%), Gefäßbiegung $(25,0 \% ; 0 \% ; \mathrm{p}<0,02)$, lineare intrathrombotische Kontrastmittelaufnahme $(37,5 \% ; 60,0 \%)$ und distale Gefäßerkrankung $(68,8 \% ; 44,0 \%)$ waren ungleich zwischen den Erfolgsgruppen verteilt. Unter der Annahme eines Grenzwertes von 4 oder mehr Punkten ergab sich eine Sensitivität von 31,3\%, Spezifität von $100 \%$, negativer $69,4 \%$ und positiver prädiktiver Wert $100 \%$. Die Komplikationsrate des Herzkatheters betrug $9,8 \%$ und die mittlere applizierte Kontrastmittelmenge $234,4 \mathrm{ml}$.

Schlussfolgerung: Die Anwendung des auf 5 CTAKriterien basierendem Punktesystem ermöglichte bei unseren Patienten eine Vorhersage des CTORevaskularisationserfolg mit hohem positivem prädiktivem Wert und hoher Spezifität bei allerdings niedriger Sensitivität und negativem prädikti-

\section{Abstract \\ $\nabla$}

Objective: Analyzing occluded segments with computed tomography angiography (CTA) prior to percutaneous coronary intervention (PCI) increased revascularization success in chronic total occlusions (CTO). The aim of our study was to develop a scoring system for the prediction of PCI success in CTO. Materials and Methods: 41 consecutive СТО patients (30 male; 63.1 years $+/-8.3$ standard deviation) underwent CTA prior to $\mathrm{PCl}$. All CTOs were categorized by two radiologists in consensus regarding the presence of special features and without knowledge of PCI outcome. All outcome criteria were evaluated. Afterwards one point was assigned for each unequally distributed outcome criteria per CTO and all points were added up to a single score.

Results: Severe calcifications (failure group $68.8 \%$ vs. success group $28.0 \% ; \mathrm{p}<0.02)$ and intraluminal calcifications (68.8\%; 40.0\%), tortuosity $(25.0 \% ; 0 \% ; \mathrm{p}<0.02)$, linear intrathrombus enhancement $(37.5 \%$; $60.0 \%)$ and distal vessel disease $(68.8 \% ; 44.0 \%)$ were unequally distributed. By adopting a threshold of 4 points or higher (maximum 5 points), the results were: sensitivity $31.3 \%$, specificity $100 \%$, negative predictive value (NPV) $69.4 \%$ and positive predictive value (PPV) $100 \%$. The PCI complication rate was $9.8 \%$ and the mean contrast media amount was $234.4 \mathrm{ml}$. Conclusion: With the suggested scoring system, based on five CTA criteria, PCI failure could be predicted with high PPV and specificity in our group of patients, but the NPV and sensitivity are low. However, 5 unsuccessful PCIs (13.2\%) could have been avoided and none would have been wrongly omitted. Regarding the complication rate during $\mathrm{PCI}$ and the high amounts of contrast media needed, a prediction system appears to be desirable and should be the object of large-scale trials. 
ven Wert. Vielmehr hätten 5(13,2\%) nicht erfolgreiche Revaskularisationsversuche durch die Anwendung des Punktesystems vermieden werden können während keinem Patienten fälschlicherweise eine Intervention vorenthalten worden wäre. Auch unter Berücksichtigung der hohen Komplikationsrate und des hohen Kontrastmittelbedarfs erscheint ein solches Vorhersagesystem wünschenswert und sollte Gegenstand größerer prospektiver Studien sein.

\section{Kernaussagen:}

- Bisher konnten einzelne Prädiktoren für erfolgreiche Revaskularisationen bei CTOs detektiert werden.

- Die Erfolgsrate wird durch eine Analyse der kardialen CTA vor der Revaskularisation gesteigert.

- Ein auf 5 Kriterien basierendes Punktesystem zur Vorhersage des Revaskularisationserfolges scheint sehr vielversprechend.

- Zusätzlich wird durch das Punktwertsystem zukünftig die Patientenselektion für die richtige Behandlungsoption bei CTOs verbessert.

- Auch Risiken, Komplikationen sowie Kontrastmittelmengen und Strahlendosis können reduziert werden.

\section{Introduction}

Chronic total occlusions (CTOs) of coronary arteries occur in about $15-30 \%$ of patients with suspected or known coronary artery disease (CAD) [1 - 4]. A CTO is defined as obstruction of a native coronary artery over a period of three months showing no antegrade blood flow as assessed by coronary angiography [5-7]. CTOs are more frequently located in the RCA than in the LAD or the RCX, and the frequency increases with advanced patient age $[2,5]$. Patients benefit from revascularization with a reduction of symptoms or need for bypass surgery, improvement of left ventricular

Table 1 Potential predictors of $\mathrm{PCl}$ success.

Tab. 1 Prädiktoren des Revaskularisationserfolges.

\begin{tabular}{|lll|}
\hline & simple & complex \\
\hline vessel diameter $(\mathrm{mm})$ & $>3 \mathrm{~mm}$ & $<3 \mathrm{~mm}$ \\
\hline occlusion length $(\mathrm{mm})$ & $>2 \mathrm{~mm}$ & $<2 \mathrm{~mm}$ \\
\hline level of calcification & non-circular & circular \\
\hline intraluminal calcifications & no & yes \\
\hline occlusion stump & tapered & blunt \\
\hline ostial location & no & yes \\
\hline proximal vessel disease & absent to moderate & severe \\
\hline distal vessel opacification & good or excellent & poor \\
\hline distal vessel disease & absent or moderate & severe \\
\hline multiple occlusion & no & yes \\
\hline tortuosity & $<45$ degrees & $>45$ degrees \\
\hline LIE & yes & no \\
\hline
\end{tabular}

LIE - linear intrathrombus enhancement.
Key points:

- Single predictors of revascularization success in CTO have been identified.

- Success rates are improved by analyzing CTA data sets prior to revascularization approaches.

- Prediction of revascularization success via a scoring system based on five CTA criteria seems promising.

- Patient selection for the right treatment options might be improved in the future due to application of the scoring system.

- Also risks, complications, contrast media amounts and radiation doses might be reduced.

Citation Format:

- Roller FC, Harth S, Rixe J et al. Development and Suggestion of a Cardiac CTA Scoring System for the Prediction of Revascularization Success in Chronic Total Occlusions (CTO) of the Coronary Arteries. Fortschr Röntgenstr 2016; 188: 172-178 function and prolonged survival like previous studies showed [8-11]. Also long-term mortality is reduced after successfully performed PCI procedures [12]. Moreover, completeness of revascularization was identified as a strong predictor of survival in simultaneous CTOs [13]. Due to length variability, tortuosity, as well as histopathological structure concerning the presence and extent of calcification patterns, fibrocytes and collagen revascularizations of CTOs are known as challenging procedures and success rates vary between $55 \%$ and $80 \%$ in different series $[8,9,14-16]$. In previous studies single predictors of PCI failure and success have been identified. The length of the occluded segment, the level of mural calcifications and the presence of an intraluminal calcification, the occluded segment tortuosity (greater than 45 degrees) and vessel course visibility were identified amongst others as predictors for PCI failure $[7,8,15,17,18]$. Also the presence of linear intrathrombus enhancement (LIE), which was defined as a linear-like area of enhancement opacity traversing the non-opacified occluded segment with attenuations higher than 120 Hounsfield units (HU) by Li et al., was identified as a predictor of PCI success [19].

A recent study by Rolf et al. showed that the PCI success rate in patients undergoing pre-procedural CTA was significantly higher compared to patients without coronary CTA prior to PCI ( $90 \%$ vs. $63 \%$ ) [20].

These findings imply that analysis and characterization of CTOs by CTA with regard to special features and predictors can increase PCI success rates. To our knowledge, no statistically significant predictor combinations were identified in multivariate data analysis so far. The aim of our study was to assess whether $\mathrm{PCI}$ success in patients with CTO is predictable by a newly developed

\begin{tabular}{|lllll|}
\hline & $\begin{array}{l}\text { total } \\
\mathbf{n = 4 1}\end{array}$ & $\begin{array}{l}\text { RCA } \\
\mathbf{n = 2 3}\end{array}$ & $\begin{array}{l}\text { LAD } \\
\mathbf{n = 1 5}\end{array}$ & $\begin{array}{l}\text { LCX } \\
\mathbf{n = 3}\end{array}$ \\
\hline occlusion length & $3.6 \mathrm{~cm}$ & $4.27 \mathrm{~cm}$ & $3.0 \mathrm{~cm}$ & $1.7 \mathrm{~cm}$ \\
\hline range & $0.5-8.2 \mathrm{~cm}$ & $0.8-8.2 \mathrm{~cm}$ & $0.5-6.2 \mathrm{~cm}$ & $1.0-2.4 \mathrm{~cm}$ \\
\hline $\mathrm{PCl}$ success & $3.9 \mathrm{~cm}$ & $4.26 \mathrm{~cm}$ & $2.9 \mathrm{~cm}$ & $1.7 \mathrm{~cm}$ \\
\hline range & $0.5-8.2 \mathrm{~cm}$ & $0.8-8.2 \mathrm{~cm}$ & $0.5-4.4 \mathrm{~cm}$ & $1.0-2.4 \mathrm{~cm}$ \\
\hline PCI failure & $3.5 \mathrm{~cm}$ & $4.27 \mathrm{~cm}$ & $3.3 \mathrm{~cm}$ & - \\
\hline range & $1.0-7.7 \mathrm{~cm}$ & $1.0-7.7 \mathrm{~cm}$ & $2.2-6.2 \mathrm{~cm}$ & \\
\hline
\end{tabular}

Table 2 Occlusion lengths and correlation to outcome groups.

Tab. 2 Verschlusslängen und Korrelation zu den Erfolgsgruppen. 


\begin{tabular}{|c|c|c|c|c|c|}
\hline & $\begin{array}{l}\text { PCI failure } \\
\text { n \% }\end{array}$ & $\begin{array}{l}\text { PCl success } \\
\text { n \% }\end{array}$ & $\begin{array}{l}\text { PPV } \\
\text { n \% }\end{array}$ & $\begin{array}{l}\text { NPV } \\
\text { n } \%\end{array}$ & $\mathbf{P}$ \\
\hline \multirow[t]{2}{*}{ severe calcification } & $11 / 16$ & $7 / 25$ & $11 / 18$ & $18 / 23$ & 0.02 \\
\hline & $68.8 \%$ & $28.0 \%$ & $61.1 \%$ & $78.2 \%$ & \\
\hline \multirow[t]{2}{*}{ tortuosity } & $4 / 16$ & $0 / 25$ & $4 / 4$ & $25 / 37$ & 0.02 \\
\hline & $25.0 \%$ & $0 \%$ & $100 \%$ & $67.6 \%$ & \\
\hline \multirow[t]{2}{*}{ distal vessel disease } & $11 / 16$ & $11 / 25$ & $11 / 22$ & $14 / 19$ & 0.20 \\
\hline & $68.8 \%$ & $44.0 \%$ & $50.0 \%$ & $73.7 \%$ & \\
\hline \multirow[t]{2}{*}{ intraluminal calcification } & $11 / 16$ & $10 / 25$ & $11 / 21$ & $15 / 20$ & 0.11 \\
\hline & $68.8 \%$ & $40.0 \%$ & $52.4 \%$ & $75.0 \%$ & \\
\hline \multirow[t]{2}{*}{ LIE } & $6 / 16$ & $15 / 25$ & $6 / 21$ & $10 / 20$ & 0.21 \\
\hline & $37.5 \%$ & $60.0 \%$ & $28.6 \%$ & $50.0 \%$ & \\
\hline
\end{tabular}

Table 3 Unequally distributed СТO criteria and correlation to outcome groups.

Tab. 3 Ungleich verteilte CTOMerkmale and Korrelation zu den Erfolgsgruppen.

LIE - linear intrathrombus enhancement.

Table 4 Threshold analysis.

Tab. 4 Grenzwertanalyse.

\begin{tabular}{|l|cccl|}
\hline score & $\begin{array}{l}\text { sensitivity } \\
\mathbf{n} \%\end{array}$ & $\begin{array}{l}\text { specificity } \\
\mathbf{n} \%\end{array}$ & $\begin{array}{l}\text { PPV } \\
\mathbf{n} \%\end{array}$ & $\begin{array}{l}\text { NPV } \\
\mathbf{n} \%\end{array}$ \\
\hline 1 & $15 / 16$ & $3 / 25$ & $15 / 37$ & $3 / 4$ \\
\hline 2 & $93.8 \%$ & $12.0 \%$ & $40.5 \%$ & $75.0 \%$ \\
\hline 3 & $12 / 16$ & $10 / 25$ & $12 / 27$ & $10 / 14$ \\
\hline & $75.0 \%$ & $40.0 \%$ & $44.4 \%$ & $71.4 \%$ \\
\hline 4 & $9 / 16$ & $19 / 25$ & $9 / 15$ & $19 / 26$ \\
\hline 5 & $56.3 \%$ & $76.0 \%$ & $60.0 \%$ & $73.1 \%$ \\
\hline 5 & $5 / 16$ & $25 / 25$ & $5 / 5$ & $25 / 36$ \\
\hline & $1.3 \%$ & $100.0 \%$ & $100.0 \%$ & $69.4 \%$ \\
\hline & $1 / 16$ & $25 / 25$ & $1 / 1$ & $25 / 40$ \\
\hline
\end{tabular}

CTA scoring system, which is based on identified predictors with frequency differences between the outcome groups.

\section{Methods}

$\nabla$

The local ethics committee of our institution approved the study with patients' informed consent.

\section{Patients and ethics}

Between June 2012 and October 2013, 41 consecutive patients (30 male; mean age 63.1 years $+/-8.3$ standard deviation) underwent coronary CTA prior to elective interventional CTO recanalization at our institution. Revascularization attempts had not been previously performed in any of the included patients. A chronic total coronary occlusion was defined as the presence of a TIMI 0 (thrombolysis in myocardial infarction) flow within the occluded segment, and an occlusion duration of at minimum 3 months. Myocardial viability was tested before revascularization attempts using cardiac MRI or echocardiography. Afterwards the patients were referred to coronary CTA for characterization of the occluded segments. All CTA images showed diagnostic quality and therefore all patients could be included in the study and were available for further analysis.

\section{Coronary CTA}

All patients were examined using a dual-source 64 MDCT scanner (Somatom Definition ${ }^{\circledR}$, Siemens Healthcare, Forchheim, Germany). Contrast media were administered via an antecubital vein (18-G intravenous catheter). ECG electrodes were placed in standard po-

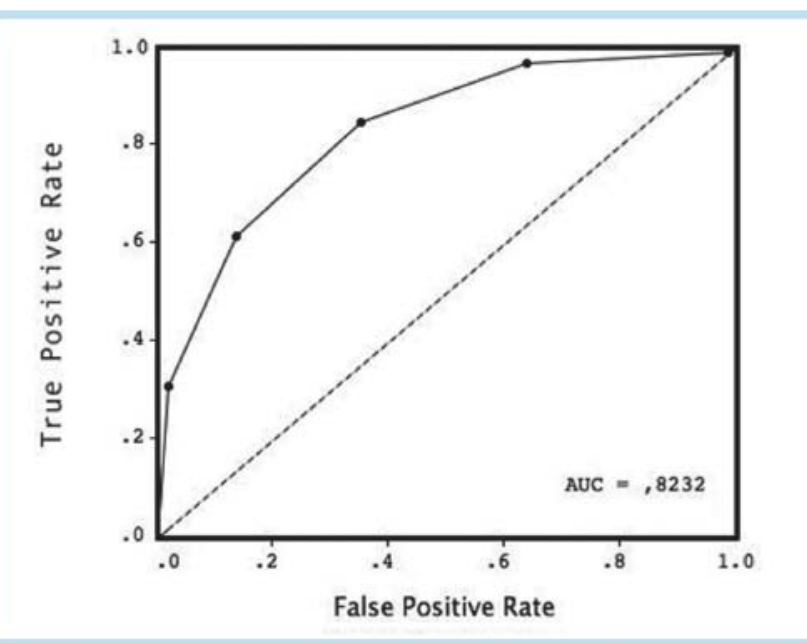

Fig. 1 ROC Curve for Scoring Threshold. The black line represents the area under the curve for the thresholds of the CTA-based scoring system. ROC receiver operating characteristic.

Abb. 1 Die schwarze Linie zeigt die Fläche unter der Kurve für die möglichen Grenzwerte des CTA-basierenden Punktesystems.

sition and all patients received $0.8 \mathrm{mg}$ of glycerol-trinitrate sublingually immediately before the CT scans. To achieve sufficient target heart rates (below 65/min), patients also received $50 \mathrm{mg}$ atenolol orally 45 minutes before imaging. Initially an unenhanced CT scan for calcification scoring was obtained. The imaging parameters were: $64 \times 0.6 \mathrm{~mm}$ collimation, reconstruction slice thickness $3 \mathrm{~mm}$ and reconstruction kernel B35 $\mathrm{f}$. The table pitch depended on the heart rate. The tube current was adapted automatically for calcification scoring using care dose $4 \mathrm{D}$ exposure control. For optimal contrast media timing, a test bolus approach was used $(10 \mathrm{ml}$ iopromide containing $370 \mathrm{mg}$ iodine/ml (Ultravist 370, Bayer Healthcare, Berlin, Germany) were injected followed by $50 \mathrm{ml}$ isotonic saline both at a rate of $6 \mathrm{ml} / \mathrm{s}$ ). Afterwards coronary CTA was performed and the contrast media amounts and radiation dose varied depending on the expected CT scan durations and field of views. The scan ranged from the level of the tracheal bifurcation to the diaphragm in a craniocaudal scan direction. All scans were acquired with retrospective ECG gating with the following imaging parameters: collimation $64 \times 0.6 \mathrm{~mm}$, tube voltage $100-120 \mathrm{kV}$ for both tubes (depending on body habits) and gantry rotation time $330 \mathrm{~ms}$. As described for calcium scoring, the table pitch depended on the individual heart rates. The ECG pulsing window was manually adapted with a preference at $70 \%$ of the RR interval. Image 


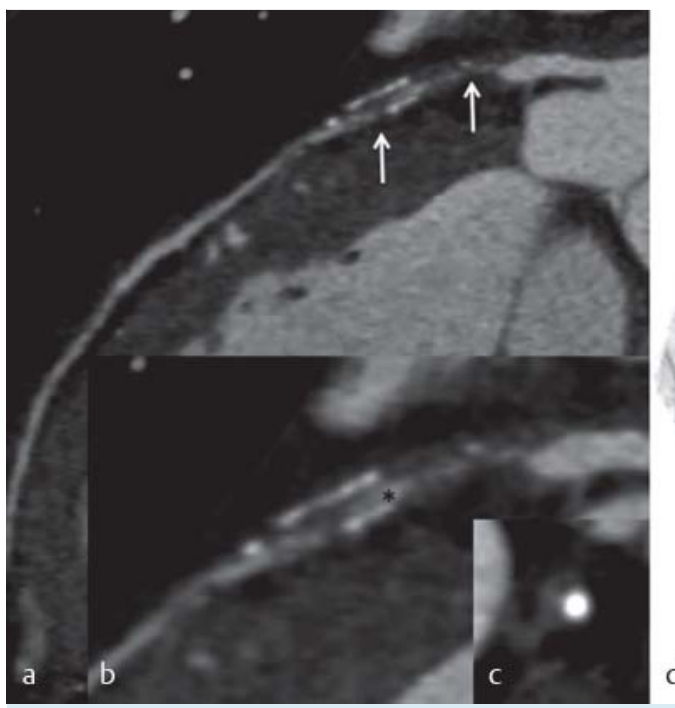

Fig. 2 Curved MPR image a and 3-dimensional MIP c of a 48-year-old patient with CTO of the proximal LAD with a length of $3.8 \mathrm{~cm}$. Inside $\mathbf{a}, \mathbf{b}$ shows magnification of the occluded segment. The occluded segment shows predisposing non-calcified plaques with severe calcifications at the vessel wall. The occlusion stump has a tapered appearance. Intrathrombus enhancement is also presented - defined as linear-like opacities in the occluded segment with attenuations greater than $120 \mathrm{HU}$. The black star in b marks the linear intrathrombus enhancement. Occlusions and linear opacities alternate within the occluded segment. The white arrows in a and the black arrows in $\mathbf{d}$ mark the occlusion entry and endpoint. Image $\mathbf{c}$ shows an orthogonal enlargement of the proximal occlusion (entrance), which is partially embarrassed by an intraluminal calcified plaque. The CTO scoring of this lesion yielded a score of 2 points ( 1 point for severe calcification and 1 point for intraluminal calcifications). Revascularization of this lesion was successful.
Abb.2 Gekrümmte MPR a und dreidimensionale MIP c eines 48-jährigen Patienten mit CTO der proximalen LAD mit einer Verschlusssegmentlänge von $3,8 \mathrm{~cm}$. Innerhalb der Abbildung a zeigt $\mathbf{b}$ eine Vergrößerung des Verschlusssegmentes. Das Verschlusssegment besteht prädisponierend aus nicht-kalzifizierten Plaques mit teils schweren randständigen Verkalkungen. Der Verschlussstumpf zeigt ein eingekerbtes Erscheinungsbild. Im Verlauf des Verschlusssegmentes ist eine intrathrombotische KM-Anreicherung vorhanden - diese ist definiert als lineare Anreicherungen im Verschlusssegment mit Werte größer als 120 HU. Der schwarze Stern in b zeigt eine solche intrathrombus KM-Anreicherung. Innerhalb des verschlossenen Abschnittes zeigt sich ein Wechselspiel von Verschlüssen und solchen linearen Anreicherungen. Der weiße Stern in a und der schwarze Pfeil in $\mathbf{d}$ markieren den Verschlussanfang und -ende. Abbildung c zeigt ein orthogonales Bild des Verschlusseinganges mit einer partiellen Verlegung mit einer großen kalzifizierten, intraluminalen Plaque. Die Anwendung des Punktesystems ergibt einen Gesamtwert von 2 Punkten (1 Punkt schwere Verkalkungen, 1 Punkt intraluminale Verkalkungen). Der Revaskularisationsversuch der CTO war erfolgreich. data was reconstructed with a slice thickness of $0.6 \mathrm{~mm}$ and an increment of $0.6 \mathrm{~mm}$. Multiplanar reconstructions (MPR), maximum intensity projections (MIP) and curved MPRs were obtained. CT postprocessing was performed on a dedicated workstation (Syngo ${ }^{\circledR}$ workplace, Siemens Healthcare, Forchheim, Germany). For all CTOs the vessel lumen and vessel diameters were measured on orthogonal images and the lengths were measured on curved MPRs.

\section{Criteria evaluation}

Two radiologists (15 and 4 years of cardiac imaging experience) analyzed and characterized all CTA images in consensus without knowledge of the PCI outcome concerning the presence or absence of LIE, intraluminal calcifications and CTA verifiable complexity criteria defined by the Euro CTO club [21]. Severe calcifications were defined as the presence of circular calcifications and intraluminal calcifications should cover at least a minimum of $50 \%$ of the vessel lumen. All proven criteria are displayed in - Table 1. The criteria distribution between the PCI success group and the PCI failure group was analyzed for all proven criteria. Unequally distributed criteria were defined as criteria with a frequency difference of greater than $20 \%$ between the outcome groups and one point was assigned for each unequally distributed criterion for each lesion. Afterwards all points were added up to a single score for each CTO and the CTO scores were related to sensitivity, specificity, positive predictive value (PPV) and negative predictive value (NPV) for each possible threshold. In addi- tion, the contrast media amounts for CTA and PCI procedures and the number of $\mathrm{PCI}$ complications were analyzed.

\section{Statistics}

Statistical analyses were performed using SPSS statistical software version 20 (IBM, New York, USA). The criteria distribution between the outcome groups was tested for statistical significance with the Chi-Square test. Data was tested for normal distribution using the Shapiro-Wilk test. In cases of normal distribution, the Student t-test was carried out and if the data did not follow normal distribution, the Mann-Whitney U-test (non-parametric) was used. All results were tested at a $5 \%$ level of significance. Receiver operating characteristic (ROC) was performed for the scoring system thresholds.

\section{Results}

$\nabla$

23 CTOs were located in the RCA (56.1\%), 15 in the LAD (36.6\%) and 3 in the LCX (7.3\%). PCI was successful in 25 cases representing an overall PCI success rate of $60.1 \%$ (RCA 11 of $23 / 47.8 \%$, LAD 11 of $15 / 73.3 \%$, LCX 3 of $3 / 100 \%$ ).

The mean lengths of the occluded segments were $3.6 \mathrm{~cm}+/-2.0 \mathrm{~cm}$ SD with a range between $0.5 \mathrm{~cm}$ and $8.2 \mathrm{~cm}$ (RCA $4.27 \mathrm{~cm}$, LAD $3 \mathrm{~cm}$, LCX $1.7 \mathrm{~cm}$ ). The mean occlusion lengths were $3.9 \mathrm{~cm}$ (RCA $4.27 \mathrm{~cm}$, LAD $3.3 \mathrm{~cm}$ ) for failed PCI and $3.5 \mathrm{~cm}$ (RCA $4.26 \mathrm{~cm}$, 


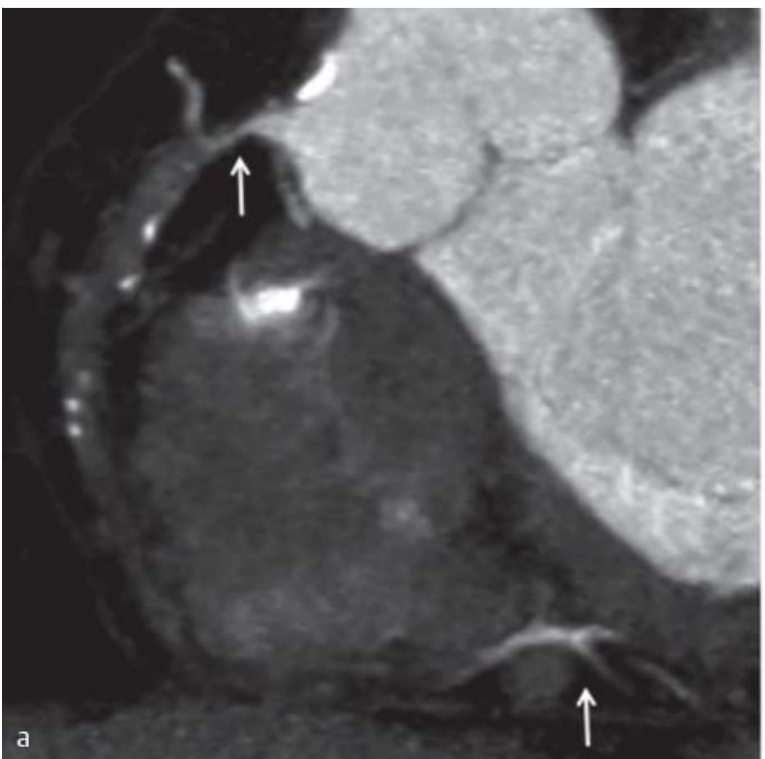

Fig. 3 Shows a CTO of the RCA in a 57-year-old patient. Image a shows an MPR with a slice thickness of $11 \mathrm{~mm}$. The occlusion has an extent of $8.2 \mathrm{~cm}$. The occlusion entry is a little proximal to the coronary ostium and the occlusion stump has a tapered appearance (white arrow). The white arrow at the bottom shows antegrade filling of the RIVP (ramus interventricularis posterior). The curved MPR $\mathbf{b}$ shows the occluded segment in a craniocaudal direction. A centerline with occlusion measurement is included. The plaques are primarily non-calcified with only small granular calcified plaques. The white arrows in $\mathbf{b}$ show the occlusion stump and the distal filling of the RPLD (ramus posterolateralis dexter). The 3-dimensional MIP shows the occlusion stump and the distal filling of the right coronary basin (black arrows). The medial and distal sections of the RCA are not visible. The СTO scoring yielded a score of 0 points in this case even though the occlusion segment has an extent of $8.2 \mathrm{~cm}$. Severe calcifications, distal vessel disease, intraluminal calcifications, tortuosity and LIE were not present. Revascularization could be successfully performed.
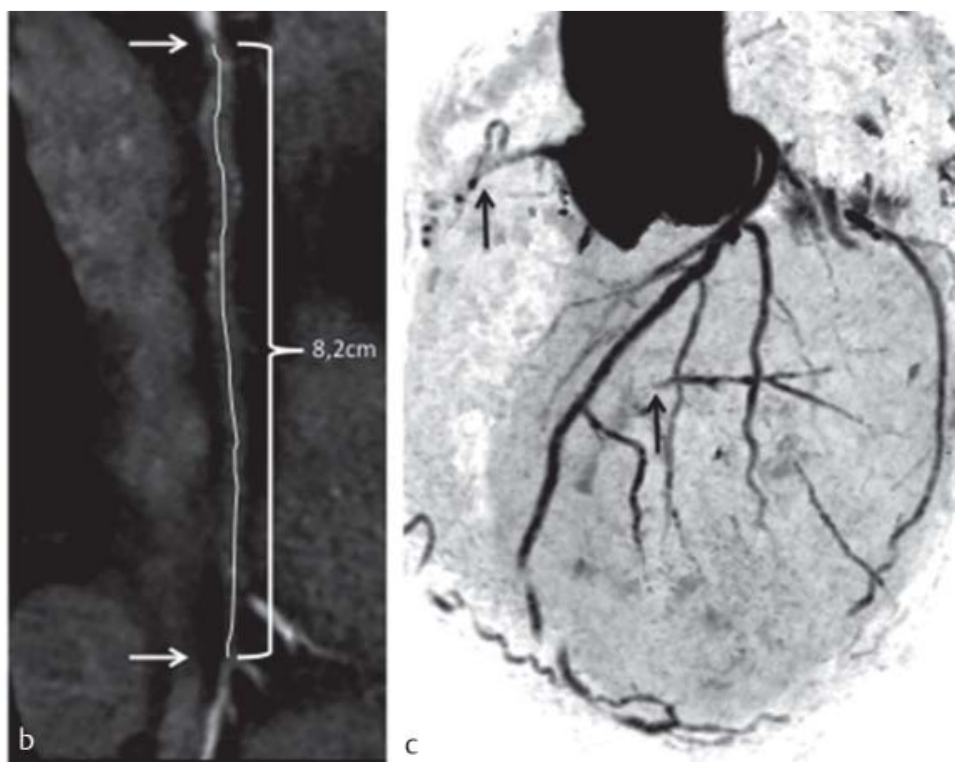

Abb. 3 Zeigt eine CTO der RCA bei einem 57-jährigem Patienten. a zeigt eine MPR mit einer Schichtdicke von $11 \mathrm{~mm}$. Die Verschlusslänge beträgt $8,2 \mathrm{~cm}$, der Verschlussanfang liegt nah am Koronarastium und hat eine eingekerbte Morphologie (weißer Pfeil). Der weiße Pfeil zeigt die retrograde Auffüllung des RVIP (Ramus interventrikularis posterior). Die gekrümmte MPR b zeigt das Verschlusssegment in kraniokaudaler Ausrichtung. Es liegen fast ausschließlich nicht kalzifizierte Plaques mit lediglich kleineren granulären randständigen Plaques vor. Der weiße Pfeil in b zeigt den Verschlussstumpf und die distale Auffüllung des RPLD (Ramus posterolateralis dextra). Zudem wurde eine „Centerline“ zur Messung der Okklusionslänge eingefügt. Die dreidimensionale MIP zeigt ebenfalls den Verschlussstumpf und die distale Wiederauffüllung des RCA Stromgebietes (schwarzer Pfeil). Die Anwendung des Punktesystems ergibt einen Gesamtwert von 0 Punkten obwohl das Verschlusssegment eine Länge von $8,2 \mathrm{~cm}$ aufweist. Der Revaskularisationsversuch der CTO war erfolgreich.
LAD $2.9 \mathrm{~cm}, \mathrm{RCX} 1.7 \mathrm{~cm}$ ) for PCI success. Successful revascularization was performed in all CTOs of the LCX. The mean occlusion lengths with regard to outcome are presented in $\bullet$ Table 2.

The mean lesion lengths were not significantly different between the outcome groups $(p=0.33)$. In our group of patients, the level of calcification, intraluminal calcification, tortuosity of the occluded segment, distal vessel disease and linear intrathrombus enhancement (LIE) were unequally distributed criteria and were therefore identified as relevant predictors according to our definition. Intraluminal calcifications were present in 11 of 16 patients (68.8\%) in the PCI failure group and in 10 of 25 patients $(40.0 \%)$ in the PCI success group $(p>0.05)$. Severe calcifications were noted in 11 of 16 patients (68.8\%) in the PCI failure group and in 7 of 25 patients (28.0\%) in the PCI success group $(p<0.05)$, whereas the tortuosity of the occluded segment was only present in 4 patients in the PCI failure group (25.0\%) $(p<0.05)$. Linear intrathrombus enhancement was present in 6 of 16 patients (37.5\%) in the PCI failure group and in 15 of 25 patients $(60.0 \%)$ in the PCI success group and distal vessel disease was present in 11 of 16 patients $(68.8 \%$ ) in the $\mathrm{PCI}$ failure group and in 11 of 25 patients (44.0\%) in the PCI success group (for both $\mathrm{p}>0.05$ ). The criteria distributions of the unequally distributed criteria are displayed in $\bullet$ Table 3.

Multiple CTOs were present in only one patient. This patient had combined CTO of the RCA and the LCX. The PCI of the RCA CTO was successful in a first session and the PCI of the LCX CTO in a second session. Due to the identification of 5 relevant unequally distributed criteria, a maximum score of 5 points for each CTO was possible.

The PCI failure group had a mean point value of $2.6+/-1.4$ SD and the PCI success group had a mean point value of $1.7+/-1.0 \mathrm{SD}$ $(p=0.02)$. The sensitivity, specificity, PPV and NPV were calculated for each threshold ( 0 to 5 points). The threshold analysis results are displayed in $\bullet$ Table 4. By adopting a threshold of 4 points (equal or higher), the corresponding sensitivity, specificity, positive predictive value (PPV) and negative predictive value (NPV) are: $31.3 \%$, $100 \%, 100 \%$ and $69.4 \%$, respectively. $\bullet$ Fig. 1 shows the ROC curve analysis for the thresholds of the scoring system.

Complications during PCI procedures occurred in 4 cases. This results in an overall complication rate of $9.8 \%$. All of these complications occurred in the PCI failure group (complication rate $25.0 \%$ ). The complications were coronary artery perforation in 3 cases and coronary artery dissection in 1 case. In a case of coronary artery perforation, cardiopulmonary resuscitation was required. Furthermore, in all of these cases the revascularization attempt was unsuccessful. The mean contrast media amounts were $234.4 \mathrm{ml}$ for the PCI procedures and $70 \mathrm{ml}$ for CTAs and the mean CTA radiation exposure was $8.78 \mathrm{mSv}$ with a range between $3.27 \mathrm{mSv}$ and $23.2 \mathrm{mSv}$.

- Fig. 2, 3 illustrate the CTA-based scoring system in two patients with successful revascularizations. 

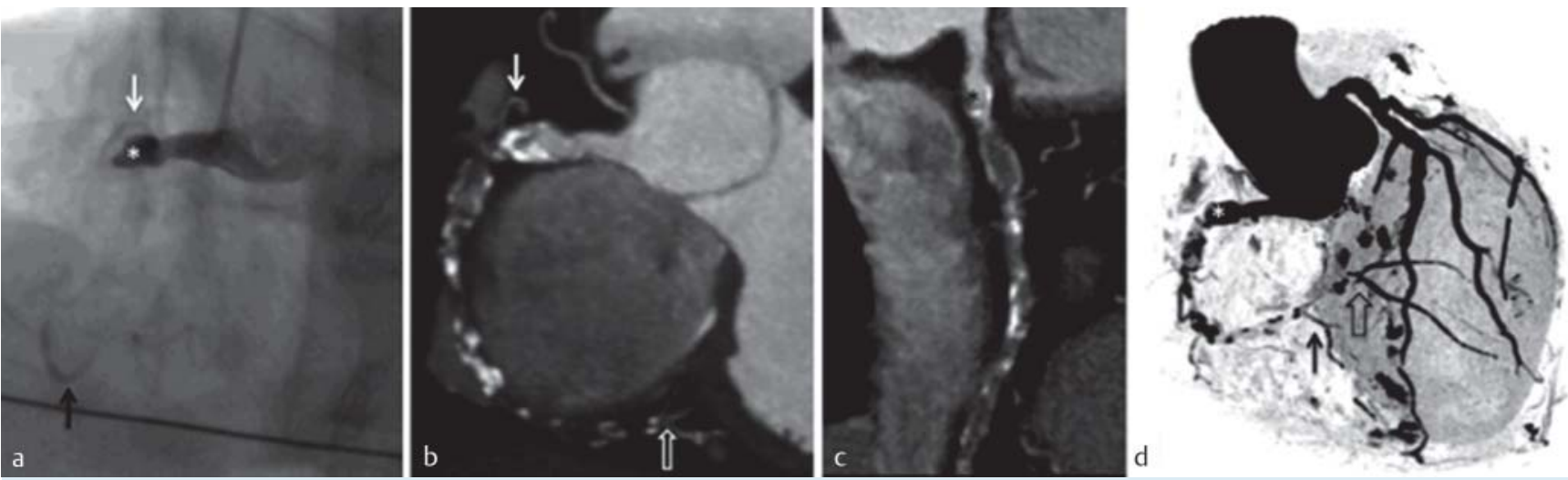

Fig. 4 Shows a selective cardiac catheter image and the reconstructed CTA images of an RCA CTO in a 56-year-old patient. In selective cardiac catheter image $\mathbf{a}$, the occlusion stump shows a blunt appearance (white star) and the white arrow marks the origin of the cone artery. In b a CTA MPR of the RCA with a slice thickness of $11 \mathrm{~mm}$ is displayed. In contrast to the catheter image, not only the cone artery (white arrow) and the stump morphology with a blunt occlusion entry but also the occlusion extent, plaque morphology, intraluminal calcifications and distal vessel contrast (white arrow) are displayed. In $\mathbf{c}$ the proximal and middle section of the RCA is displayed in a curved MPR. The black star marks the blunt occlusion stump. The occluded segment shows a mixture of calcified plaques with partial intraluminal calcifications and non-calcified plaques. The 3-dimensional MIP in $\mathbf{d}$ shows the blunt occlusion stump (white star) and the filling of the RPLD (ramus posterolateralis dexter, black arrow). The CTO scoring for this lesion yielded 4 points (severe calcifications 1 point, intraluminal calcifications 1 point, distal vessel disease 1 point and absence of LIE 1 point). Revascularization was not successful.

Abb.4 zeigt ein selektives Herzkatheterbild und rekonstruierte koronare CTA-Bilder einer 56-jährigen Patienten mit einer CTO der RCA. Im selektiven Herzkatheterbild a hat der Verschlussanfang eine stumpfe Morphologie (weißer Stern) und der weiße Pfeil zeigt den Abgang der Konusarterie. b zeigt eine $11 \mathrm{~mm}$ dicke CTA MPR der RCA. Im Gegensatz zum Herzkatheterbild ermöglicht die CTA nicht nur eine Abbildung des stumpfen Verschlussanfanges und der Konusarterie, sondern ermöglicht auch Aussagen zu der Verschlusslänge, der Plaquemorphologie, zu intraluminalen Kalzifikationen und distalen Gefäßerkrankungen (weißer Pfeil). c zeigt die Morphologie der proximalen und distalen RCA in einer gekrümmten MPR. Der schwarze Stern kennzeichnet den stumpfen Verschlussanfang, im Verschlusssegment liegen sowohl kalzifizierte und nicht-kalzifizierte Plaques aber auch intraluminale Verkalkungen vor. Die dreidimensionale MIP d zeigt den stumpfen Verschlussanfang (weißer Stern) und die distale Auffüllung des RPLD (Ramus posterolateralis dextra, schwarzer Stern). Die Anwendung des Punktesystems ergibt einen Gesamtwert von 4 Punkten (1 Punkt schwere Verkalkungen, 1 Punkt intraluminale Verkalkungen, 1 Punkt distale Gefäßerkrankung, 1 Punkt für das Fehlen einer linearen intrathrombotischen KM-Aufnahme). Der Revaskularisationsversuch war nicht erfolgreich.

\section{Discussion}

CTOs are often characterized by high complexity. Single predictors of $\mathrm{PCI}$ outcome have been identified in previous publications $[7-9,17,18]$. Also the influence of pre-procedural CTA prior to PCI has been investigated and showed a favorable effect for revascularization success compared to a control group without CTA prior to PCI [20]. This effect might likely be attributed to better knowledge of occlusion anatomy and morphology. The advantage of CTA in this context is obvious ( $\bullet$ Fig. 4). In contrast to PCI, CTA is able to display the whole occluded segment and not only the occlusion stump when antegrade blood flow is absent or low retrograde fillings of the coronary artery basin are present. The aim of our study was to assess and to identify relevant outcome criteria, which are unequally distributed over the outcome groups, with the goal of developing a CTA-based scoring system to enable PCI outcome prediction in patients with CTO. To the best of our knowledge, this is the first attempt in this context. The overall PCI success rate of $60.1 \%$ in our group of patients was comparable to the success rates published by other groups $[8,9,14-16]$ and also the RCA was predominantly affected as described in many previous studies.

Severe calcifications, intraluminal calcifications, absence of LIE, distal vessel disease and tortuosity of the occluded segment showed an influence on PCI failure. Other criteria like lesion length didn't show any influence on revascularization success in our group of patients. The identification of these 5 relevant success criteria might be supported by physiological considerations and characteristics. Severe and/or intraluminal calcifications complicate guiding wire support due to the presence of hard and impassable plaque material and in cases of tortuosity. When steering through an occlusion on a bend, which is typically located in the proximal RCA, subintimal dissections are common due to directing of the guide wire in the outer part of the curve [22]. Retrograde revascularization approaches and guiding wire support are especially limited by the presence of severe distal vessel disease, and LIE, which is discussed as being associated with the presence of intraluminal microvessels (detected in histological examinations and varying in size between 100 and $500 \mu \mathrm{m}$ ), might otherwise support guide wire crossing in CTOs [19].

By adopting a threshold of 4 points (equal or higher), the CTO scoring system resulted in a sensitivity of $31.3 \%$, specificity of $100 \%$, NPV of $69.4 \%$ and PPV of $100 \%$. Despite the low sensitivity and NPV, the great specificity and PPV might enable patient filtering for right treatment options in the future. Patients who would definitely profit from PCI and patients in whom PCI does not seem to be a promising alternative could be identified. Considering our results, 5 of $41 \mathrm{PCI}$ procedures (12.2\%) could have been omitted by using and adapting the CTA-based CTO scoring system. The clinical application of the scoring system might also be related to increased PCI success rates. In our patient collective the success rate could have been increased from $60.5 \%$ to $69.4 \%$ by using the scoring system. Moreover, the overall complication rate of $9.8 \%$ ( $25.0 \%$ in the patients with failed $\mathrm{PCI}$ ), the mean $\mathrm{PCI}$ contrast media amount of $234.4 \mathrm{ml}$ and also the associated radiation exposures (in previously performed studies, mean PCI radiation exposures of $40 \mathrm{mSv}$ were reported [21]) underline the need for preventing non-suitable patients from undergoing PCI proce- 
Table 5 CTO score calculator.

Tab. 5 CTO-Punktwert-Kalkulator.

\begin{tabular}{|c|c|c|}
\hline & definition & scoring \\
\hline $\begin{array}{l}\text { severe } \\
\text { calcification }\end{array}$ & presence of circular calcifications & 1 point \\
\hline tortuosity & $\begin{array}{l}\text { presence of tortuosity of occluded } \\
\text { segment }\end{array}$ & 1 point \\
\hline $\begin{array}{l}\text { distal vessel } \\
\text { disease }\end{array}$ & $\begin{array}{l}\text { presence of calcified or non-calcified } \\
\text { plaques distal to the occluded segment }\end{array}$ & 1 point \\
\hline $\begin{array}{l}\text { intraluminal } \\
\text { calcification }\end{array}$ & $\begin{array}{l}\text { presence of intraluminal calcifications, } \\
\text { which cover at least a minimum of } 50 \% \\
\text { of the vessel lumen }\end{array}$ & 1 point \\
\hline LIE & $\begin{array}{l}\text { absence of linear-like areas of enhance- } \\
\text { ment opacity traversing the non-opaci- } \\
\text { fied occluded segment with attenua- } \\
\text { tions higher than } 120 \mathrm{HU}\end{array}$ & 1 point \\
\hline total & >4 points - difficult lesion & $\square$ points \\
\hline
\end{tabular}

dures. Nevertheless, this is accepted by radiation and contrast media exposures for pre-procedural CTA. In our group of patients, the mean CTA contrast media amount was $70 \mathrm{ml}$ and the mean radiation dose was $8.78 \mathrm{mSv}$. Based on our results, $\odot$ Table 5 presents a CTO score calculation sheet for clinical usage.

However, our approach has some study limitations. As a main limitation, our study is only performed as a retrospective singlecenter analysis in a relative small group of patients. The study populations in previously performed CTO CTA outcome studies were mostly larger and ranged between 30 and 139 patients [19-21, 23]. Otherwise, studies dealing with CTA-based CTO success prediction or predictor identification are rare. Another limitation is that up to now only two of the determined relevant success predictors are statistically significant (severe calcification and tortuosity of the occluded segment). The other identified predictors are still insignificant, which is certainly owned by our small study population.

Also the ongoing technical development of new guiding wires and cardiac catheters today and in the near future might influence revascularization outcomes due to technical improvement. It should also be assumed that new CT scanner generations with dual-source applications might also improve morphologic characterization of occluded segments in the future.

Nonetheless, the result seems promising in our group of patients. In order to avoid high contrast media amounts, radiation exposure and complication rates, which are associated with failed PCO revascularizations in unsuitable patients, the suggested approach should be the object of large-scale trials.

\section{Conclusion}

$\nabla$

Summarized, our study showed that a CTO scoring system - only based on five relevant criteria identified by CTA prior to PCI might be a promising diagnostic tool to improve patient selection for PCI but also to prevent patients from risks of less promising PCI procedures in the future. Large-scale trials should be performed to verify these first results.

\section{References}

1 Fefer $P$, Knudtson ML, Cheema AN et al. Current perspectives on coronary chronic total occlusions: the canadian multicenter chronic total occlusions registry. J Am Coll Cardiol 2012; 59: 991 -997
2 Cohen HA, Williams DO, Holmes DR et al. Impact of age on procedural and1-year outcome in percutaneous transluminal coronary angioplasty: the NHLBI Dynamic Registry. Am Heart J 2003; 146: 513-519

3 Kahn JK. Angiographic suitability for catheter revascularization of total coronary occlusions in patients from a community hospital setting. Am Heart J 1993; 126: 561-564

4 Christofferson RD, Lehmann KG, Martin GV et al. Effect of chronic total coronary occlusion on treatmentstrategy. Am J Cardiol 2005; 95: $1088-1091$

5 Hoe J. CT coronary angiography of chronic total occlusions of the coronary arteries: how to recognize and evaluate and usefulness for planning percutaneous coronary interventions. Int J Cardiovasc Imaging 2009; 25: $43-54$

6 Stone GW, Kandzari DE, Mehran R et al. Percutaneous recanalization of chronically occluded coronary arteries: a consensus document: part I. Circ Cardiovasc Imaging 2005; 112: 2364-2372

7 DiMario C, Werner G, Sianos G et al. European perspective in the recanalisation of Chronic Total Occlusions (CTO): consensus document from the EuroCTO Club. Eurolntervention 2007; 3: 30 - 43

8 Olivari Z, Rubartelli P, Piscione F et al. Immediate results and one-year clinical outcome after percutaneous coronary interventions in chronic total occlusions: data from a multicenter, prospective, observational study (TOAST-GISE). J Am Coll Cardiol 2003; 41: 1672 - 1678

9 Mehran R, Claessen BE, Godino C et al. Long-term outcome of percutaneous coronary intervention for chronic total occlusions. JACC Cardiovasc Interv 2011; 4: $952-961$

10 Jones DA, Weerackody $R$, Rathod $K$ et al. Successful recanalization of chronic total occlusions is associated with improved long-term survival. JACC Cardiovasc Interv 2012; 5: 380-388

11 Khan MF, Wendel CS, Thai HM et al. Effects of percutaneous revascularization of chronic total occlusions on clinical outcomes: a meta-analysis comparing successful versus failed percutaneous intervention for chronic total occlusion. Catheter Cardiovasc Interv 2013; 82: 95 - 107

12 Joyal $D$, Afilalo J, Rinfret $S$. Effectiveness of recanalization of chronic total occlusions: a systematic review and metaanalysis. Am Heart J 2010; 160: 179-187

13 Danzi GB, Valenti R, Migliorini R et al. Percutaneous Coronary Intervention for Multiple Chronic Total Occlusions. Am J Cardiol 2013; 112: $1849-1853$

14 Suero JA, Marso SP, Jones PG et al. Procedural outcomes and long-term survival among patients undergoing percutaneous coronary intervention of a chronic total occlusion in native coronary arteries: a 20-year experience. J Am Coll Cardiol 2001; 38: 409-414

15 Stone GW, Reifart NJ, Moussa I et al. Percutaneous recanalization of chronically occluded coronary arteries: a consensus document: part II. Circ Cardiovasc Imaging 2005; 112: 2530-2537

16 Galassi AR, Tomasello SD, Reifart $N$ et al. In-hospital outcomes of percutaneous coronary intervention in patients with chronic total occlusion: insights from the ERCTO (European Registry of Chronic Total Occlusion) registry. EuroIntervention 2011; 7: 472 - 479

17 Noguchi T, Miyazaki MS, Morii I et al. Determinants of primary success and long-term clinical outcome. Catheter Cardiovasc Interv 2000; 49: $258-264$

18 Tan KH, Sulke N, Taub NA et al. Determinants of success of coronary angioplasty in patients with a chronic total occlusion: a multiple logistic regression model to improve selection of patients. Br Heart J 1993; 70: $126-131$

19 Li M, Zhang J, Pan J et al. Coronary Total Occlusion Lesions: Linear Intrathrombus Enhancement at CT Predicts Better Outcome of Percutaneous Coronary Intervention. Radiology 2013; 266: 443-451

20 Rolf A, Werner GS, Schuhbäck A et al. Preprocedural coronary CT angiography significantly improves success rates of $\mathrm{PCI}$ for chronic total occlusion. Int J Cardiovasc Imaging 2013; 29: 1819-1827

21 Garcia-Garcia HM, van Mieghem CA, Gonzalo $M$ et al. Computed Tomography in Total coronary Occlusions (CTTO Registry): radiation exposure and predictors of successful percutaneous intervention. Eurointervention 2009; 4: 607-616

22 Stone GW, Colombo A, Teirstein PS et al. Percutaneous Recanalization of Chronically Occluded Coronary Arteries: procedural techniques, devices and results. Catheter Cardiovasc Interv 2005; 66: 217-236

23 Soon $\mathrm{KH}$, Cox N, Wong A et al. CT coronary angiography predicts the outcome of percutaneous coronary intervention of chronic total occlusion. J Interv Cardiol 2007; 20: 359-366 